\title{
Neumonía necrotizante inducida por Escherichia coli extraintestinal patogénica (ExPEC) en felinos
}

\author{
Francisco Carvallo Chaigneau
}

MV, DCs, DACVP, Departamento de Patología Animal, Facultad de Ciencias Veterinarias y Pecuarias, Universidad de Chile. Av. Santa Rosa 11735, La Pintana, Santiago. Email: fcarvallo@u.uchile.cl

\begin{abstract}
Resumen
La Escherichia coli extraintestinal patogénica (ExPEC) es una de las bacterias más comunes encontradas en el tracto gastrointestinal de humanos y animales. ExPEC se caracteriza por producir enfermedad en otros órganos fuera del tracto gastrointestinal. Este grupo ha sido implicado en infecciones del tracto urinario, meningitis, septicemia y neumonía en humanos y animales. En este estudio se muestran las implicancias de distintas ExPEC en el desarrollo de neumonía en un refugio para gatos, en donde mueren de manera abrupta 13 de 35 gatos; y en un tigre recientemente destetado y transportado en una caja para un programa de televisión. En todos los casos, se observa neumonía necrotizante y fibrinosa, con la presencia de colonias bacterianas intralesionales. El cultivo y la tipificación de los genotipos de virulencia demuestran la presencia de factores que son comunes para estas bacterias, como son hemolisina $\mathrm{D}$, papGI y papGIII y cnf-1. Como patogenia, se propone que una vez inhalada la bacteria, la presencia de hemolisina y cnf-1 reduce la respuesta inflamatoria aguda en pulmón, bloqueando la llegada e induciendo muerte de neutrófilos, disparando además edema, necrosis e inflamación. Interesantemente, hemolisinas y cnf-1 son encontrados en ExPEC aisladas de humanos que padecen infecciones del tracto urinario y otros sitios extraintestinales. En conclusión, Las infecciones por ExPEC en felinos es una entidad emergente, que se caracteriza por el desarrollo de neumonía necrotizante que es frecuentemente fatal, y que este agente tiene un potencial zoonótico debido a su similitud entre las bacterias aisladas en humanos y animales, sumado a la cercanía entre ambas especies.
\end{abstract}

